\title{
Septo-optic dysplasia - Case report
}

\author{
Displasia septo-óptica - Relato de caso
}

\author{
Paulo de Tarso P. Pierre Filho' \\ Lucas Borelli Bovo ${ }^{1}$ \\ Ana Maria Marcondes ${ }^{3}$
}

Trabalho realizado na Universidade Estadual de Campinas (UNICAMP).

${ }^{1}$ Residente de Oftalmologia do Departamento de OftalmoOtorrinolaringologia da Universidade Estadual de Campinas (UNICAMP).

${ }^{2}$ Professora Assistente, Doutora do Departamento de Oftalmo-Otorrinolaringologia da UNICAMP.

Endereço para correspondência: Rua Pedro Vieira da Silva, 415 Ap.01 Bloco A CEP 13080-570 - Campinas (SP) E-mail: paulopierre@ hotmail.com

Recebido para publicação em 07.04.2003

Versão revisada recebida em 04.07.2003

Aprovação em 12.12.2003

\begin{tabular}{l} 
ABSTRACT \\
\hline The clinical triad of septo-optic dysplasia (SOD) comprises the absence \\
of the septum pellucidum, congenital optic nerve dysplasia, and multiple \\
endocrine disorders. When any two of these factors are present, the \\
condition is defined as an incomplete form of SOD. The authors report the \\
case of an incomplete form of SOD in a 9-year-old boy with low vision and \\
nystagmus present from birth. The bilateral ophthalmoscopic examination \\
revealed small papillae with double contour images. Magnetic resonance \\
imaging showed hypoplasia of the optic nerve bilaterally, chiasm and \\
absence of the septum pellucidum.
\end{tabular}

Keywords: Optic disc/pathology; Optic disc/abnormalities; Optic nerve/pathology; Optic nerve/abnormalities; Optic nerve diseases/diagnosis; Septo-optic dysplasia/congenital; Septum pellucidum/abnormalities; Case report

\section{INTRODUCTION}

Septo-optic dysplasia (SOD) is a rare congenital syndrome characterized by an absent septum pellucidum, a primitive optical vesicle, and dysplasia of the optic nerve, chiasm and tract. This syndrome was described by De Morsier in 1956 who found in nine of 36 patients with agenetic septum pellucidum an association with optic nerve hypoplasia ${ }^{(1)}$. Optic nerve hypoplasia is mandatory for the diagnosis and results in a variable degree of decreased vision.

The clinical association of SOD with pituitary hormone deficiency was established in $1970^{(2)}$. Its pathogenesis is still unknown but it has been associated with low maternal age and nulliparity ${ }^{(3-5)}$.

We report the case of an incomplete form of SOD and describe the methods by which the diagnosis was documented.

\section{CASE REPORT}

Male, born at 40 weeks of gestation, with a weight of $3.4 \mathrm{~kg}$ after a normal pregnancy and labor. He was the first child of nonconsaguineous parents. The mother was 18-years-old at delivery and denied exposure to alcohol or drugs. The infant had an uncomplicated hospital course and was discharged after two days.

He was referred to our hospital at the age of nine due to complaints of low visual acuity and nystagmus from birth. Physical examination revealed a $130-\mathrm{cm}$-tall boy with normal findings at a general medical examination. His visual acuity (Snellen) was 20/100 on the right and 20/200 on the left that could not be improved with refraction. Both pupils responded normally to direct and consensual light. Versions were normal and rotatory nystagmus was present. Ophthalmologic examination disclosed pale, small-sized optic 
discs, encircled by a hypopigmented avascular scleral crescent, characterizing a double contour of the papilla (double ring sign) (Figure 1). The retinal vessels and macula were normal.

Magnetic resonance imaging revealed absence of the septum pellucidum (Figure 2), hypoplasia of the optic nerves (Figure 3) and chiasm. Endocrinologic test results (basal cortisol, adrenocorticotropic hormone, growth hormone, thyroid stimulating hormone, serum thyroxine, testosterone) were normal. A diagnosis of septo-optic dysplasia was established.

\section{DISCUSSION}

Septo-optic dysplasia has been described as a malformation of the central nervous system characterized by the absence of the septum pellucidum, and hypoplasia of the chiasm and optic nerves. It was first described by De Morsier in $1956^{(1)}$. The full syndrome was described in $1970^{(2)}$ by Kaplan et al. who presented six patients with pituitary hormone deficiency, optic nerve hypoplasia and midline abnormality of the prosencephalon. Optic nerve hypoplasia may occur in normal individuals or in those with disorders of the central nervous system. It is generally bilateral but it can be asymmetrical or unilateral $^{(6)}$.

The cause of septo-optic dysplasia remains uncertain. Interestingly, as reported in other reports ${ }^{(3-5)}$, our patient was associated with low maternal age and nulliparity.

There is a wide variability of the clinical picture. Usually patients with SOD come to medical attention for signs related to decreased visual acuity, such as congenital nystagmus, or small stature.

In some cases, intellectual and neurological development as well as language and behavior of SOD patients have been described as normal. Williams et al. ${ }^{(7)}$ studied a group of chil-

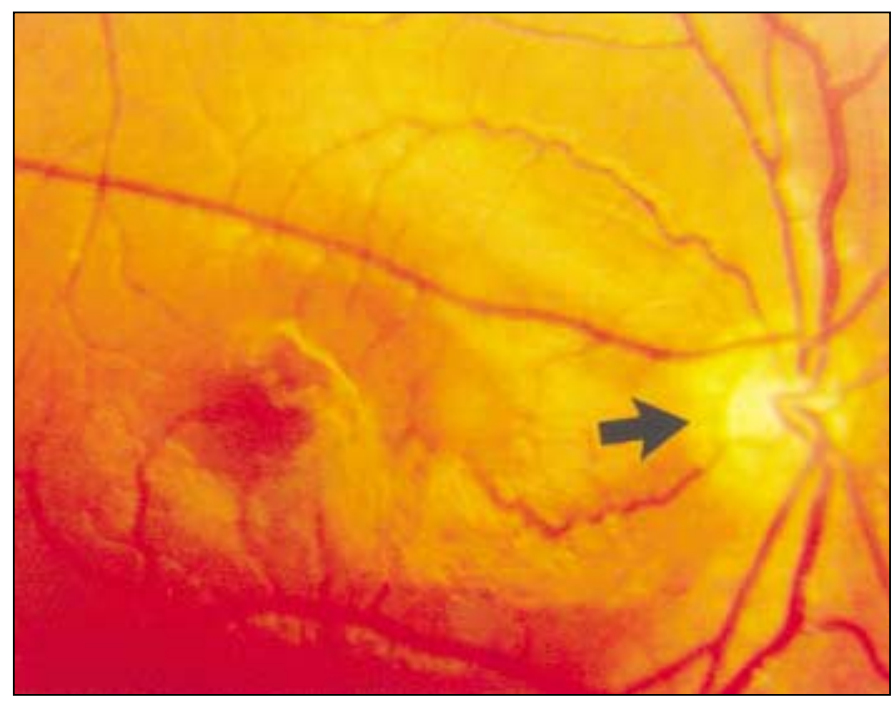

Figure 1 - Photograph of the retina demonstrating the double ring appearance of a hypoplastic optic disc dren with SOD and noted that an absent septum pellucidum was not associated with important neurological and intellectual deficiencies. Approximately two thirds of the SOD patients suffer from hypothalamic-pituitary dysfunction. The most commonly affected hypopituitary hormone is growth hormone. Hypopituitarism may become apparent at any age.

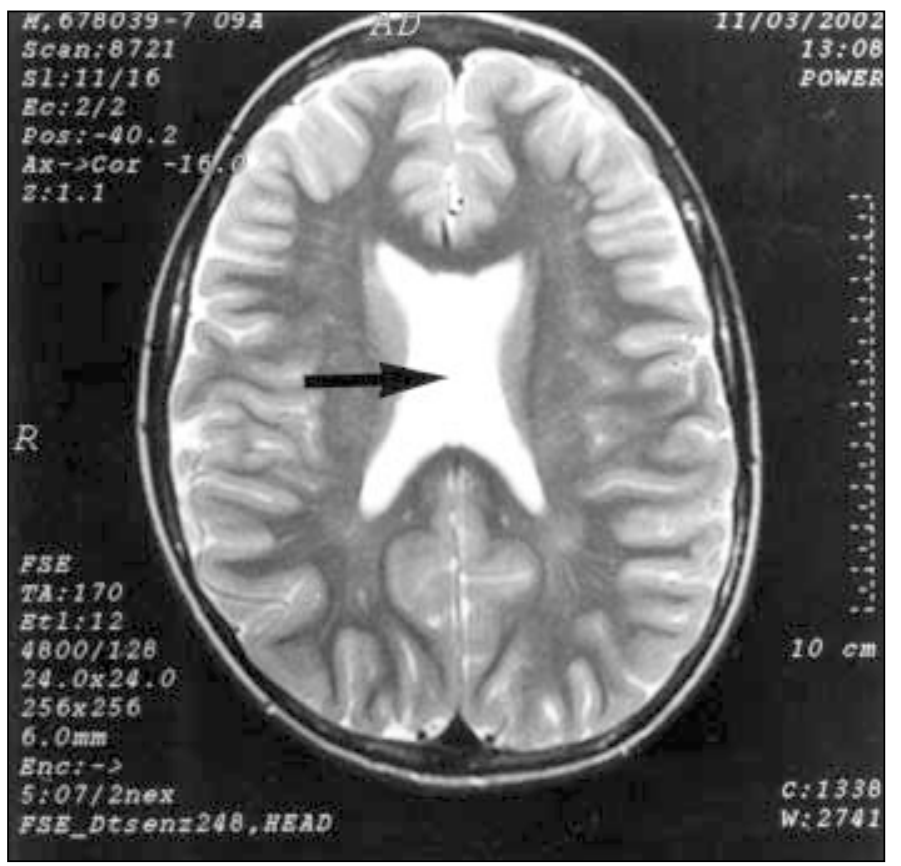

Figure 2 - Axial magnetic resonance imaging of the brain revealing absence of the septum pellucidum

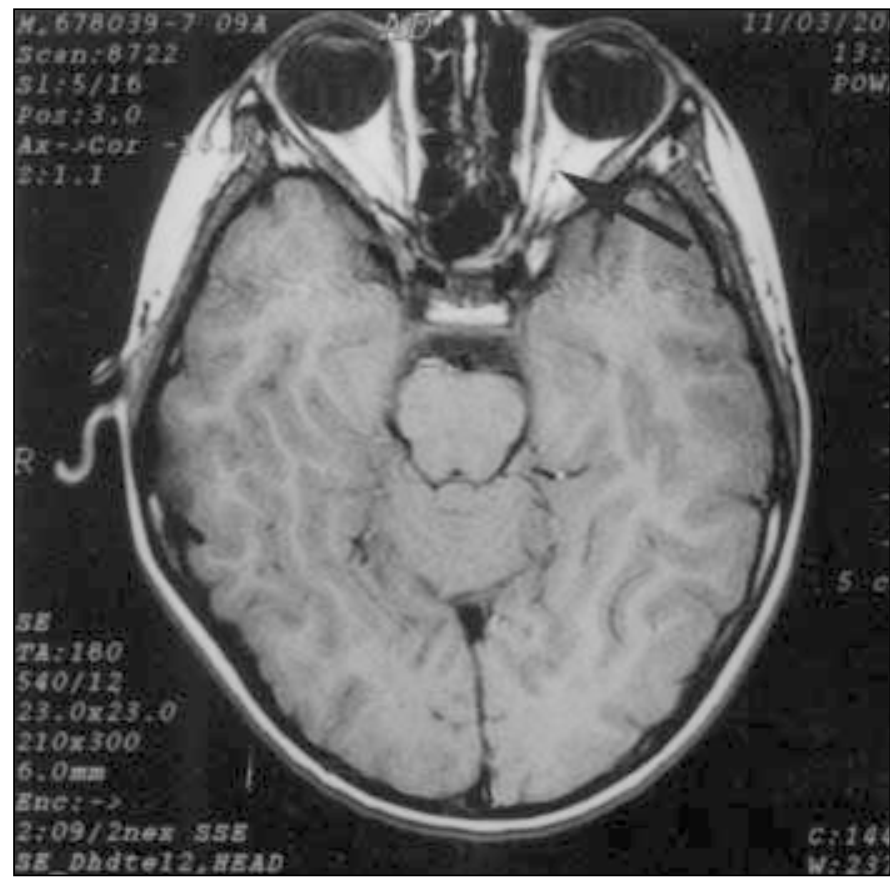

Figure 3 - Axial magnetic resonance imaging demonstrating hypoplasia of the optic nerves 
Although early onset is most common, absence of endocrine deficiencies does not preclude the development of endocrine deficiencies in later life ${ }^{(8)}$.

A fundoscopic examination reveals a small optic disc encircled by a halo of hypopigmented tissue caused by hypoplasia of the retinal epithelial pigment. The retinal vessels are normal $^{(6)}$.

The wide spectrum of anatomical malformations of the brain and optic apparatus in SOD can be visualized by magnetic resonance imaging or computed tomography.

A diagnosis of septo-optic dysplasia should be suspected in patients who have a visual deficiency and a congenital nystagmus as well as a fundoscopic examination that reveals a double image of the papilla, an imaging examination showing agenesis of the septum pellucidum, and hypophyseal or hypothalamic hormonal deficiencies.

Our case reinforces the notion that SOD may be a relatively benign entity and remain unsuspected. Our patient's intelligence was normal. He had no evidence of pituitary dysfunction. It is important to note that patients with SOD need longterm neurological, ophthalmological and endocrinological investigation.

\section{RESUMO}

A tríade clínica da displasia septo-óptica (DSO) compreende a ausência de septo pelúcido, displasia congênita do nervo óptico e múltiplos defeitos endócrinos. Uma forma incompleta de DSO tem sido reconhecida com dois dos três elementos. Os autores relatam um caso de displasia septo-óptica na forma incompleta em um garoto de 9 anos com baixa visão e nistagmo presentes desde o nascimento. $\mathrm{O}$ exame oftalmoscópico revelou papila pequena com imagem em duplo contorno bilateralmente. Ressonância magnética mostrou hipoplasia dos nervos ópticos, quiasma e ausência do septo pelúcido.

Descritores: Disco óptico/patologia; Disco óptico/anormalidades; Nervo óptico/patologia; Nervo óptico/anormalidades; Doenças do nervo óptico/diagnóstico; Displasia septoóptica/patologia/congênito; Septo pelúcido/anormalidades; Relato de caso; Criança; Masculino

\section{REFERENCES}

1. De Morsier G. Études sur les dysraphies cranio-encéphaliques. III. Agénésie du septum pellucidum avec malformation du tractus optique: la dysplasie septo-optique. Schweiz Arch Neurol Psychiatr. 1956;77(1-2):267-92.

Texto inglês: [Studies on malformation of cranio-encephalic sutures.III. Agenesis of the septum lucidum with malformation of the optic tract].

2. Kaplan S, Grumbach MM, Hoyt W. The syndrome of hypopituitary dwarfism, hypoplasia of optic nerves and malformation of prosencephalon: report of 6 patients. Pediatr Res. 1970;4:480-1.

3. Lippe B, Kaplan SA, La Franchi S. Septo-optic dysplasia and maternal age. Lancet. 1979;2(8133):92-3.

4. Purdy F. Maternal factors in septo-optic dysplasia. J Pediatr. 1979;95(4):661.

5. Lambert SR, Hoyt CS, Narahara MH. Optic nerve hypoplasia. Surv Ophthalmol. 1987;32(1):1-9.

6. Davis GV, Shock JP. Septo-optic dysplasia associated with see-saw nystagmus. Arch Ophthalmol. 1975;93(2):137-9.

7. Williams J, Brodsky MC, Griebel M, Glasier CM, Caldwell D, Thomas P. Septo-optic dysplasia: the clinical insignificance of an absent septum pellucidum. Dev Med Child Neurol. 1993;35(6):490-501.

8. Willnow S, Kiess W, Butenandt O, Dörr HG, Enders A, Strasser-Vogel B, et al. Endocrine disorders in septo-optic dysplasia (De Morsier syndrome) evaluation and follow up of 18 patients. Eur J Pediatr. 1996;155(3):179-84.

\section{ENCONTRO DA ACADEMIA AMERICANA DE OFTALMOLOGIA}

\section{3 a 26 de Outubro de 2004 New Orleans - Louisiana - U.S.A.}

